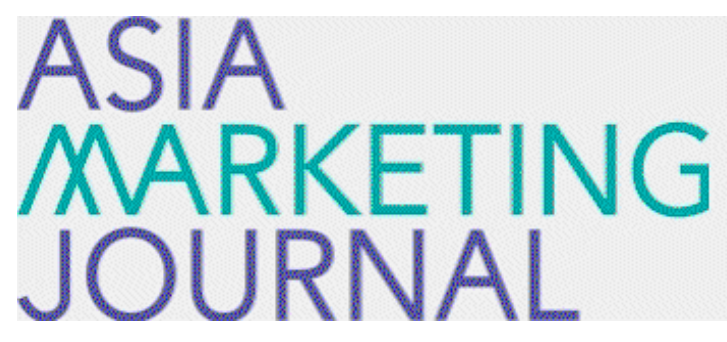

ASIA MARKETING JOURNAL

Volume 14 | Issue 3

Article 8

$10-30-2012$

\title{
Global Marketing Strategies of INNOCEAN Worldwide "Global Marketing Company, INNOCEAN Worldwide
}

Kyoung Hee Chu

Doo Hee Lee

Jong Ho Lee

Yoo

Follow this and additional works at: https://amj.kma.re.kr/journal

Part of the Marketing Commons

\section{Recommended Citation}

Chu, Kyoung Hee; Lee, Doo Hee; Lee, Jong Ho; and Yoo (2012) "Global Marketing Strategies of INNOCEAN Worldwide "Global Marketing Company, INNOCEAN Worldwide," Asia Marketing Journal: Vol. 14 : Iss. 3 , Article 8.

Available at: https://doi.org/10.53728/2765-6500.1493

This Article is brought to you for free and open access by Asia Marketing Journal. It has been accepted for inclusion in Asia Marketing Journal by an authorized editor of Asia Marketing Journal. 


\title{
Global Marketing Strategies of INNOCEAN Worldwide "Global Marketing Company, INNOCEAN Worldwide"*
}

\author{
Kyounghee $\mathrm{Chu}^{* *}$ \\ Doo-Hee Lee*** \\ Jong-Ho Lee Le** $^{* * *}$ \\ Weon Sang Yoo*****
}

\begin{abstract}
Established in May 2005. INNOCEAN Worldwide started as an affiliate marketing and communications company of the Hyundai Motor Group and grew into a top agency ranked no. 2 in the South Korean market within seven years. Currently. INNOCEAN Worldwide has become a global company, operating in sixteen countries through four regional headquarters, fifteen overseas subsidiaries, and seven branch offices with more than 1,100 employees. The company holds top clients from finance, electronics, telecommunications, food, retail, education and other various industries.

The accomplishment of INNOCEAN Worldwide can be summarized by the following five key factors. The first factor is INNOCEAN Worldwide's strong and enduring passion and commitment to enter the global market and to build and strengthen its global network. The second factor is achieving successful localization through recruiting talented employees for its overseas branches directly from the local workforce, which enables the company to overcome language barriers, cultural differences, and creative gaps among different regional markets. Third is the company's effective implementation of the 'Global Resource Remix' strategy, which incorporates the distinctive competencies of each overseas operation as a global company standard. Fourth is the creation of the "Discover System, a global knowledge management system enabling overseas offices worldwide to share each other's accumulated knowledge and experiences. The fifth factor is the successful establishment of INNOCEAN Worldwide's unique Total Marketing Solution Service. Through this service, the company has offered integrated consulting services for strategic brand management to solve various marketing problems.

In summary, the passion and commitment of INNOCEAN Worldwide's top management for the company's globalization and the supporting system that enables such commitment have made it possible for the company to take a global leap and become not merely a company with global operations but a truly global company.
\end{abstract}

Key words: INNOCEAN Worldwide, Advertising industry, Global marketing strategy, Globalization

* The authors acknowledge the helpful research support provided by Ji Hyearn Park(Research Assistant).

** Doctoral Candidate. Korea University Business School(750202@korea.ac.kr)

*** Professor, Korea University Business School(dhlee@korea.ac.kr)

**** Associate Professor. Korea University Business School(jongholee@korea.ac.kr)

***** Associate Professor, Korea University Business School(wyoo@korea,ac.kr), Corresponding author 


\section{Introduction}

Network and communication are becoming increasingly important in today's business. Global operations in many countries and effective communication among them have become a critical success factor for companies to survive the global market. This study investigates the case of INNOCEAN Worldwide, which started out as a domestic marketing and communications company and developed into an internationally competitive global company, and examines the factors that have enabled its success.

\subsection{Introduction of INNOCEAN Worldwide}

INNOCEAN Worldwide started out as an affiliated company of the Hyundai Motor Group in May 2005. As shown in Table 1, INNOCEAN Worldwide grew into the second largest marketing and communications company in the domestic market within seven years of establishment (3.4 trillion Korean Won Billing in 2011).' Currently, INNOCEAN Worldwide has become a global company, operating in sixteen countries through four regional headquarters, fifteen sub- sidiaries, and seven branch offices with over 1,100 employees. The company now holds top clients from finance, electronics, telecommunications, food. retail, education and other various industries.

The company has achieved domestic and international recognition through winning the Grand Prix at the 2011 Korea Advertising Awards for two consecutive years and also winning the Effie Awards, an international marketing competition. This study examines the success factors behind the company's domestic and international success in a short period of time.

\subsection{INNOCEAN Worldwide's Management Philosophy}

INNOCEAN Worldwide's management philosophy is to realize people's dream by creating a new future through ingenious thinking and continuously challenging new frontiers. As a global marketing and communications company, INNOCEAN Worldwide pursues a vision to deliver the greatest value through the realization of innovative communications based on creative thinking and frontier spirit. The company also sets Challenge, Customer, People, Collaboration, and Globality as their five core values, and

1) Billing indicates the general size of a marketing and communications company. If clients spend 100 billion Korean won on advertisements per year with the $\mathrm{AD}$ company, this becomes the company's billing. Marketing and communications companies charge commission by serving as an agent for clients TV. News, Magazine, and other media advertisements. and this commission becomes the $\mathrm{AD}$ company's revenue. There are two reasons why marketing company's evaluation is based on the billing. The first reason is the historical practice of the media-oriented commission system. The second reason is that billing is more objectively representative of the scale of a company rather than the revenue comprising of various profit generating structures.

138 ASIA MARKETING JOURNAL Vol. 14 No. 03 October 2012 
〈Table 1〉 Billing of Major Advertising Companies in South Korea

\begin{tabular}{|c|c|c|c|}
\hline \multicolumn{4}{|c|}{ Total Billing of Major Advertising Companies in South Korea } \\
\hline Rank & Company name & $\begin{array}{c}2011 \\
\text { Total Billing }\end{array}$ & $\begin{array}{c}2012 \\
\text { Total Billing }\end{array}$ \\
\hline 1 & Cheil Worldwide & 2.919 .859 & $4,153,201$ \\
\hline 2 & Innocean Worldwide & 2.698 .585 & 3.489 .140 \\
\hline 3 & HS AD & 557.968 & 615.153 \\
\hline 4 & Daehong Communication & 494.952 & 539.047 \\
\hline 5 & SK Marketing\&Company & 380.818 & 427.379 \\
\hline 6 & TBWA Korea & 276.756 & 309.937 \\
\hline 7 & LBEST & 183.687 & 266.475 \\
\hline 8 & Hancomm & 170.425 & 191.815 \\
\hline 9 & Dentsu media korea & 74.302 & 171.132 \\
\hline 10 & Wellcomm & 183.025 & 157.960 \\
\hline ource & tising Trend (2012) & $<$ unit & illion KRW> \\
\hline
\end{tabular}

they are described in Figure 1. It is notable hat being the global marketing and communizations company through global orientation and communicating with the world is the key corporate objective. The pursuit of the global orien- tation combined with high ideals and a broad perspective on the global market is the factor that not only provides a solid foundation for the company to enter the global market but also enables the company to utilize the experiences

〈Figure 1〉 INNOCEAN Worldwide's Core Values

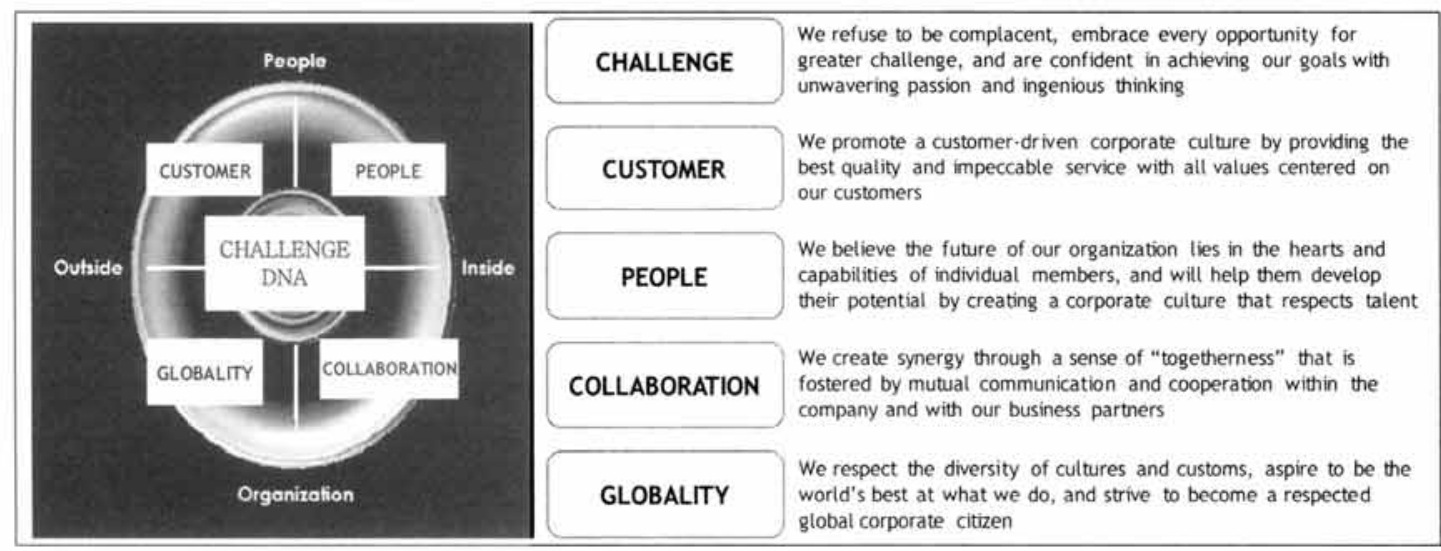


and newly acquired competencies overseas as an asset to gain a unique competitive advantage in the domestic market.

\section{Global Business}

In accordance with 'Global Orientation,' a part of INNOCEAN Worldwide's management philosophy, the company places a strong emphasis on its global business. As illustrated in Figure 2, since its foundation in May 2005. INNOCEAN Worldwide established a subsidiary in India and subsequently overseas subsidiaries including the United States, Canada, Beijing, Shanghai and a joint venture company (INNOCEAN Century Beijing Advertising Corp. (CBAC)) in China, Australia, United Kingdom, Italy, Russia, Spain. France, Turkey and Brazil, totaling up to fifteen branches in sixteen countries. Through fifteen overseas offices, INNOCEAN Worldwide has obtained the highest level of global networks and offered differentiated marketing and communication services with fresh ideas and creative products through various global experiences and information collected from business cases of competing international brands. The actual billing of INNOCEAN Worldwide's overseas business took up $74 \%$ of its total

〈Figure 2〉 INNOCEAN Worldwide's Global Network

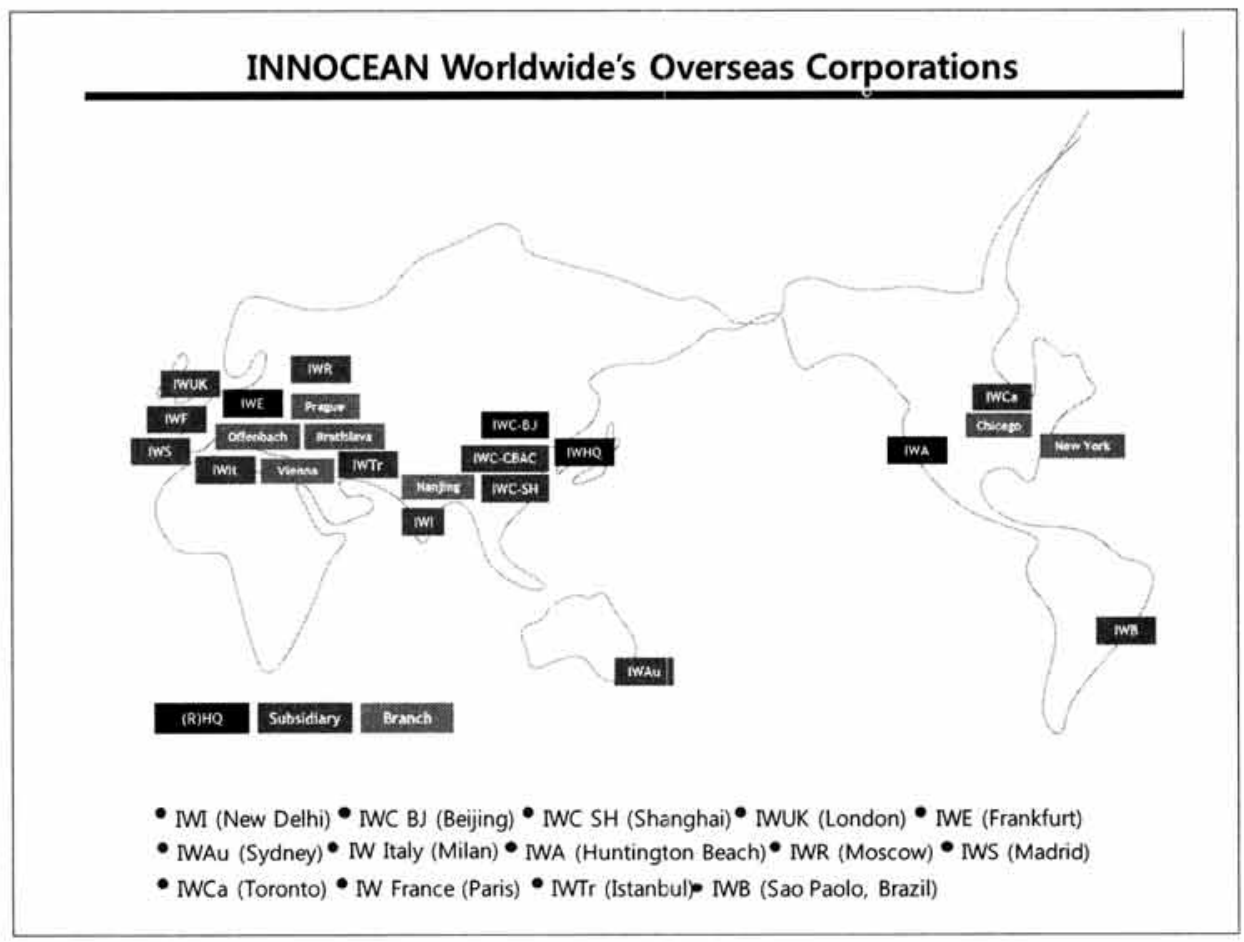

140 ASIA MARKETING JOURNAL Vol. 14 №. 03 October 2012 
business in 2009 and $78 \%$ in 2011, which is very high in the industry when compared to Cheil Worldwide's $59 \%$ of the total Billing in 2009 and $66 \%$ in 2011.

\subsection{INNOCEAN Worldwide's Global Vision}

Then, what does "Globalization" mean to INNOCEAN Worldwide? The globalization of INNOCEAN Worldwide follows the company's founding philosophy. When the company was founded in 2005, the Hyundai Motor Group had two important tasks. One was to satisfy the need for a global network agency, and the other was to improve the brand competency of Hyundai Motors. In order to increase the export of Hyundai Motor's automobiles and to escape the price-focused marketing strategy in the overseas market, the need for a global network agency to revamp the brand image of Hyundai Motors became evident. At the time, Hyundai Motors was relatively a latecomer in the overseas market, thus it was difficult for the company to find the right global agency. Consequently. the Hyundai Motor Group founded its own marketing and communications agency to enhance its brand competency.

INNOCEAN Worldwide was established to gain global leadership by competing with leading companies from developed countries in the advertising and contents industry. Furthermore. in keeping with the founding philosophy, INNOCEAN
Worldwide has made relentless efforts to become a global marketing and communications company rather than a domestic advertising company.

\subsection{What Global Business Means to INNOCEAN Worldwide}

What does global business mean to INNOCEAN Worldwide? For INNOCEAN Worldwide, overseas expansion into the global advertising and communications market was not an option but an obligation because of the following two reasons. The first reason concerns INNOCEAN Worldwide's founding philosophy. The company had an inherent mission to help Hyundai Motors enhance brand competency in the overseas market. The second reason is that global business means an opportunity for INNOCEAN Worldwide to venture unlimited business opportunities outside of the highly saturated domestic market, where the firms face mutually exhaustive competition. Accumulating know-how from global experiences and building competency overseas have served as a major asset of the company. and they created a competitive edge for the company in the domestic market as well as in the global market.

\section{Core Competency Analysis}

INNOCEAN Worldwide aims to become a 
truly global company in both quantitative and qualitative aspects. First in quantitative aspects, the company has expanded the global business domain in two ways: a) the company expanded the service regions of the existing clients, and b) the company identified new regional clients and explored new types of business. In qualitative aspects, the company made various efforts to globalize its employee base to improve the workforce's regional management capability, and worked to offer effective client services through creating a global networking infrastructure and system. One of the most important factors of INNOCEAN Worldwide's global growth strategy is the localization based on a "Challengefriendly DNA" (Momentum Leadership. This is your moment, own it!). This section analyzes the core competencies of INNOCEAN Worldwide, characterized by effective execution of localization strategies and the standardization of global marketing strategies.

\subsection{Global Operation}

INNOCEAN Worldwide has a system centralized around the regional headquarters, operating four main regional headquarters, fifteen overseas subsidiaries, seven offices, and five teams at the headquarter in Seoul, South Korea. There are 698 employees total in the Overseas Business Group, consisting of 48 employees in the head office, 36 expatriates, and 605 local employees in the overseas offices. INNOCEAN
Worldwide implements two strategies simultaneously, one being the localization strategy for countries where the regional headquarters are present and the other being standardized marketing strategy for regions such as Africa, the Middle East, South and Central Americas, and parts of Asia and East Europe where regional offices have not been set up. What is noticeable about the organization chart of INNOCEAN Worldwide in Figure 3 is that the overseas offices are under the regional headquarters system.

A noteworthy strategy that INNOCEAN Worldwide employs is to provide direct and full* capital investment but ensure maximum autonomy for the regional headquarters when the company enters a new regional market. (* Except the joint venture company, INNOCEAN Century Beijing Advertising Corporation (CBAC) INNOCEAN Worldwide owns $51 \%$ of the shares.) Presently, INNOCEAN Worldwide has stepped closer to achieving a comprehensive geographical networking structure, having established fifteen offices in sixteen countries including the United States, Canada, China (Beijng. Shanghai, INNOCEAN CBAC), Australia, India, the United Kingdom, Italy, Russia, Spain, France, Turkey, and Brazil. INNOCEAN Worldwide is building a functional networking system centered on marketing and communications professionals in the media, digital, and sports marketing, and this functional networking system is expected to become a competitive asset for the company in the future. 
〈Figure 3〉 INNOCEAN Worldwide's Organization Chart

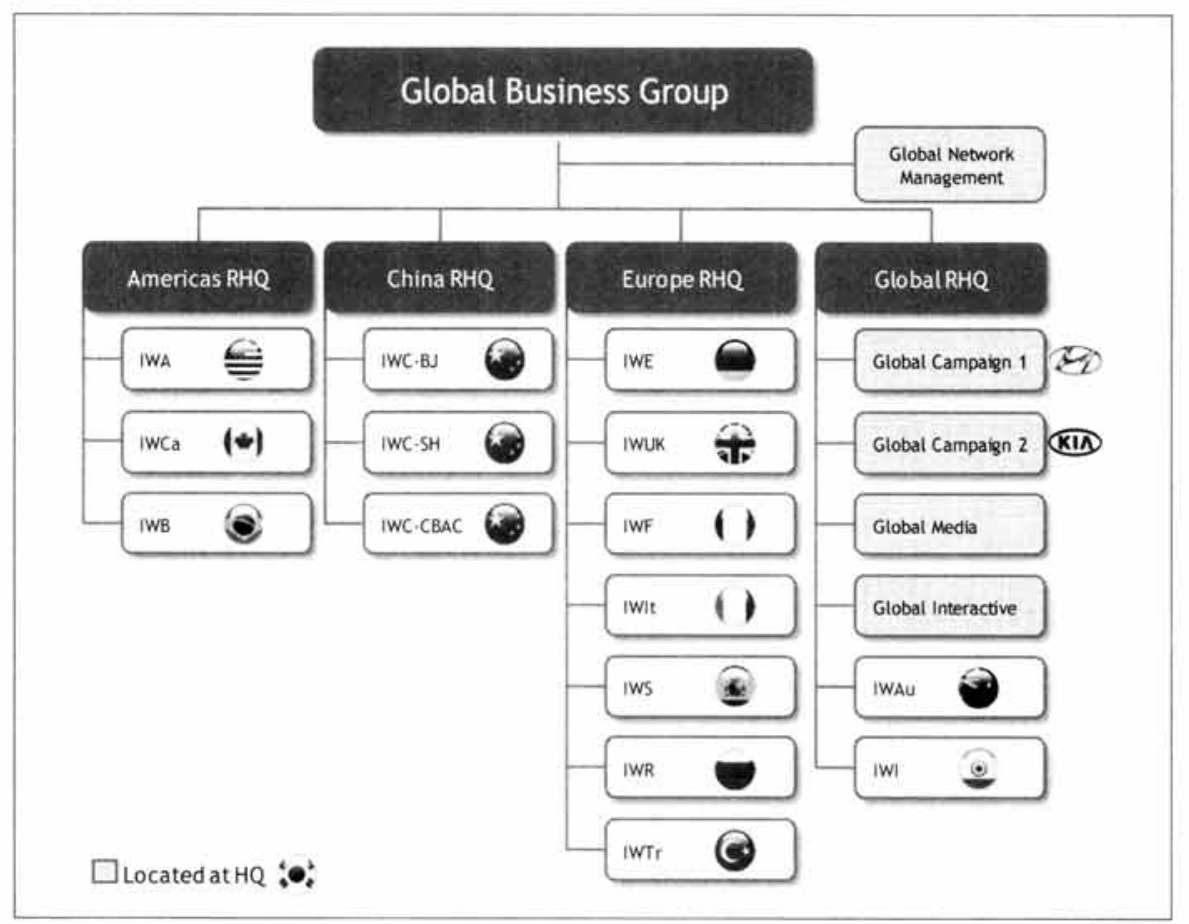

\section{〈Various Overseas Market Entry Strategies〉}

Companies use various approaches to enter the overseas markets including entry by import and exports, entry by contract, and entry by direct investments. First, entry by import and exports can be categorized into two ways. One is to indirectly export the products through a trading company and the other is a more direct way by utilizing local selling agents, local retailers, overseas branches or corporation. Another way to enter the overseas market is by contract. The licensing method, by which companies can sell the rights for an exclusive asset, as well as franchising. technology contracts, service contracts, management contracts, co-management contracts, and turnkey productions all fall into this latter category. The last method is direct investment. Direct investment methods include joint venture, establishment of subsidiary companies, or merging with or acquiring a foreign company. (Chang 2002: Daniel and Radebaugh 1998).

\subsection{Local Workforce Employment System}

INNOCEAN Worldwide aims its overseas offices to become more than offices that are simply located overseas. As the company aspired to offer the most appropriate services in the area with its overseas offices, it started employing local talents. This was intended to offer a marketing service that is most effective for the local markets by overcoming language barriers. cultural differences, and creative gaps. The expatriates who are dispatched from the head- 
quarters are those who have global capabilities and excellent communication skills. This is for INNOCEAN Worldwide to propagate its core values and vision to all regions so that all overseas offices can maintain the same objective. However, INNOCEAN Worldwide aims to complete the localization process by gradually minimizing the number of expatriates from the headquarters in the overseas offices.

\subsection{Global Resource Remix Strategy}

In this section, we explore INNOCEAN Worldwide's unique 'Global Resource Remix' strategy. INNOCEAN Worldwide's 'Global Remix Strategy' is considered as one of the key factors that has established the company as a truly global com- pany, alongside the organizational structure that enables maximum autonomy of regional offices and the local employment system.

The 'Global Remix Strategy' is a strategy standardizing successful overseas offices' unique capabilities acquired from the local markets and establishing a global standard for INNOCEAN Worldwide. In other words, if there are successful areas by each region, the company will globally implement the outstanding region's practice for comprehensive application.

For example, INNOCEAN Worldwide's Europe headquarters display strengths in promotion and exhibition while the America's headquarters offer strengths in creative, media, SNS, and digital services. As illustrated in Figure 4, the company manages a system that can globally

〈Figure 4〉 Global Resource Remix Strategy

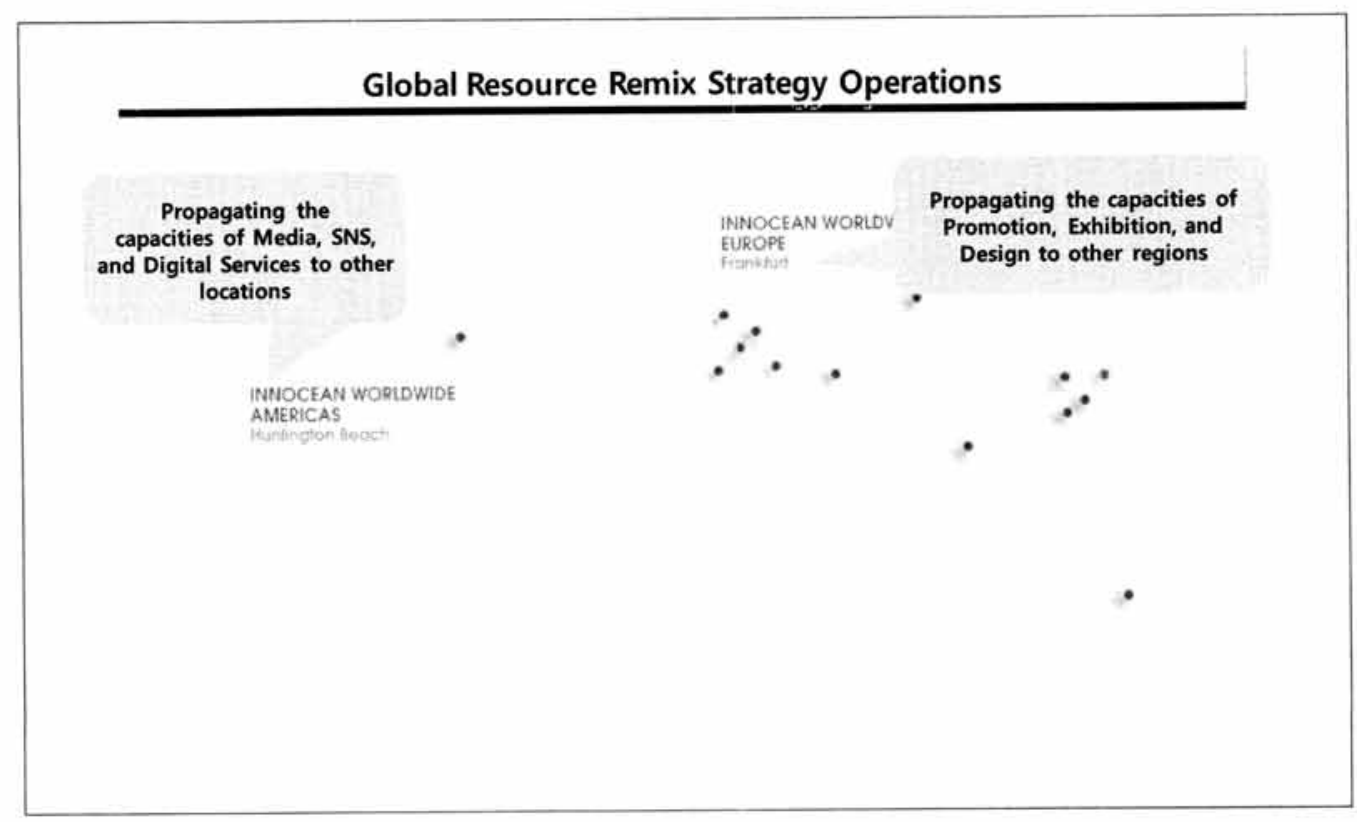

144 ASIA MARKETING JOURNAL Vol. 14 No. 03 October 2012 
propagate each region's unique experience and know-how to other branches and regional offices. The final decision is still subject to each local office's autonomy but the knowledge sharing itself enables mutual development among the regional offices all over the world.

\subsection{Strengthening the Global Capacity}

As the business scope of INNOCEAN Worldwide expanded, the company deemed the strengthening of the global capacity of all network employees as one of the most important competency a global marketing and communications company can have. This is a rather more comprehensive concept than having employees with the relevant language skills for each regional office. This means the company needs to equip its employees not only with the proper language skills but also with the ability to understand the cultural and social context of each regional market. Truly understanding the local market enables the employees to provide seamless communication between the regional offices and the headquarters, and enables the headquarters to offer its vision while also being able to gain a comprehensive understanding of the regional office's creative works.

INNOCEAN Worldwide is devoting a lot of efforts to become a true global company. First, the company has provided a well designed language training program and offered free language education. Therefore, the employees at the headquarters can learn English. Chinese, Spanish, and other various languages all year long through the company. Second, the company offers opportunities for the headquarter employees to experience the latest cultural trends overseas. The program is called 'Creative Adventure. It offers the participant to choose a region and an exploration theme, and to partake in a two-week cultural experience travel under an autonomous plan. Furthermore, the company implements various programs including overseas internships and exchange employment programs between overseas corporations and the headquarters.

\subsection{Discover System: A Global Knowledge Management System}

In addition to the institutional efforts discussed in the previous section, INNOCEAN Worldwide has been trying to build a comprehensive global knowledge management system. This system is called the 'Discover System. The Discover System started operating in January 2011 and it is the company's unique on-line library, which currently accumulates over 23,000 cases of knowledge information in its system database. The Discover System is not simply a system to register, share, and apply knowledge in a tactical level, but a system operated to achieve a bigger goal of integrated knowledge management. As summarized in Figure 5. INNOCEAN Worldwide's knowledge management started 
with the goal of 1) Obtainment of client-focused knowledge leadership through knowledge sharing. 2) Improvement of information accessibility through sharing information on works and projects, 3) Enhancing individual/company competency through sharing the best practices. The Discover System strengthens not only the domestic operations but also the network among the company's overseas offices worldwide. The global system installed in each overseas office enables all employees of INNOCEAN Worldwide to access any information registered with "Global Discover. The system is currently operated in Europe, India, Australia, the United States, Canada, and Brazil offices.

The Discover System has four main categories: Project, Job Intelligence, Market Intelligence, and Pitch Intelligence. Project accumulates advanced knowledge obtained by various businesses projects initiated by clients. Job Intelligence ac- cumulates management and job-related knowledge to support the employees' professional competencies. Market Intelligence accumulates category-specific information and case-based knowledge from each industry. Pitch Intelligence accumulates knowledge concerning the knowhows from each employee handling various advertising projects.

The Discover System is actively used within INNOCEAN Worldwide and has achieved visible results. INNOCEAN Worldwide was able to significantly reduce the employees' task completion time in creative development by offering the 'Creative Pot' menu in the Discover System, which enables employees to organize the headline, slogan, keyword, and brand names within the system. Moreover, through the IMC Idea Bank, the Discover System enables users to search IMC ideas sorted by the advertising client's characteristics or goals. It significantly

〈Figure 5〉 INNOCEAN Worldwide's Global Knowledge Management Objective

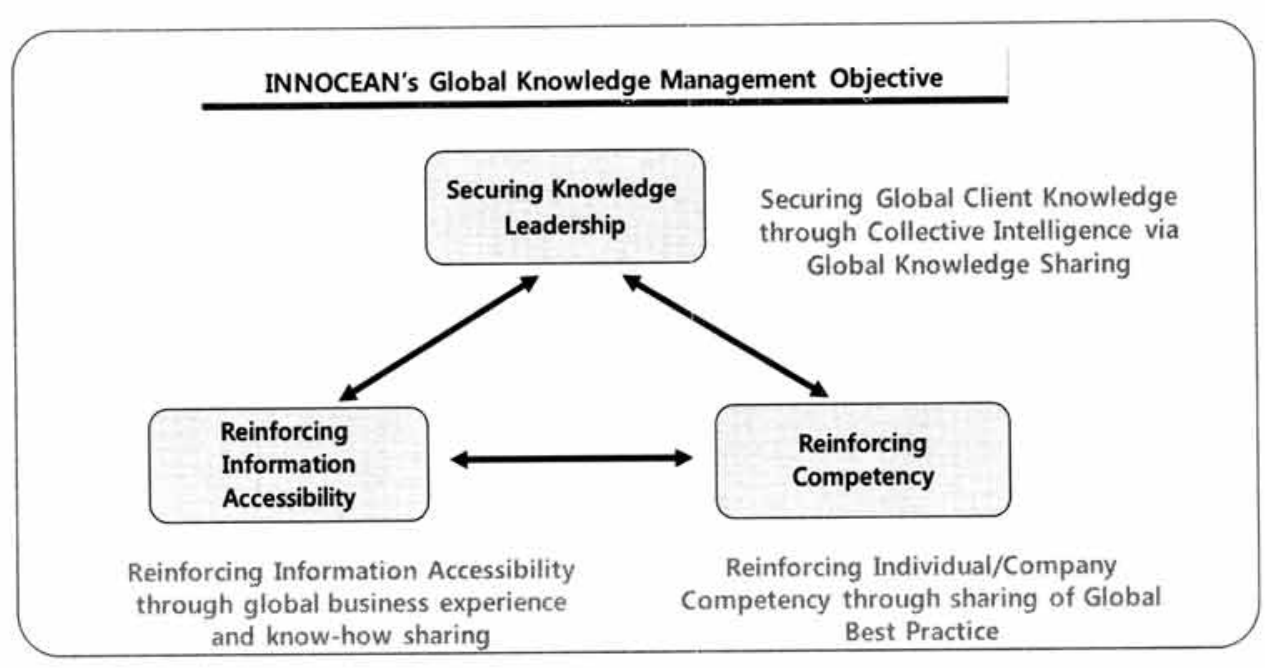

146 ASIA MARKETING JOURNAL Vol. 14 No. 03 October 2012 
reduces the physical time spent on data collection of cases and studies for various situations.

\subsection{Offering Total Marketing Solution and Consulting Services}

From brand diagnosis and consumer analysis to case analysis, INNOCEAN Worldwide offers a total marketing and consulting service for strategic brand management that employs a comprehensive and multi-angle approach. The most representative products offered by INNOCEAN Worldwide are I-BEAM, I-CORP. BRAND PERSONALITY COMPASS, ADKA, INNOCATCH, and INNO-NOW (Figure 6).

I-BEAM is an abbreviated acronym for INNOCEAN Brand Equity Assessment Model, which is INNOCEAN Worldwide's unique program to assess a brand asset in terms of quality perception, emotion, and affect. Then, strategic implications are drawn from such assessments.

ADKA is another name for the AD Keyword Analysis program. It serves as an effective tool to detect the trends of advertising keywords by analyzing the morphemes of advertisement texts.

Another program effectively utilized in the INNOCEAN Worldwide's total marketing solution is the I-CORP, in short for INNOCEAN Corporate Reputation Power. Utilizing this program offers insight into the public's comprehensive awareness and perception of corporate reputation, and enables evaluation of the brand reputation as well. The value of this program is that the brand equity is assessed based on not only specific consumer segments but also general public for an extended analysis.

In addition, INNOCEAN Worldwide imple-

〈Figure 6〉 Total Marketing Solution \& Consulting Service

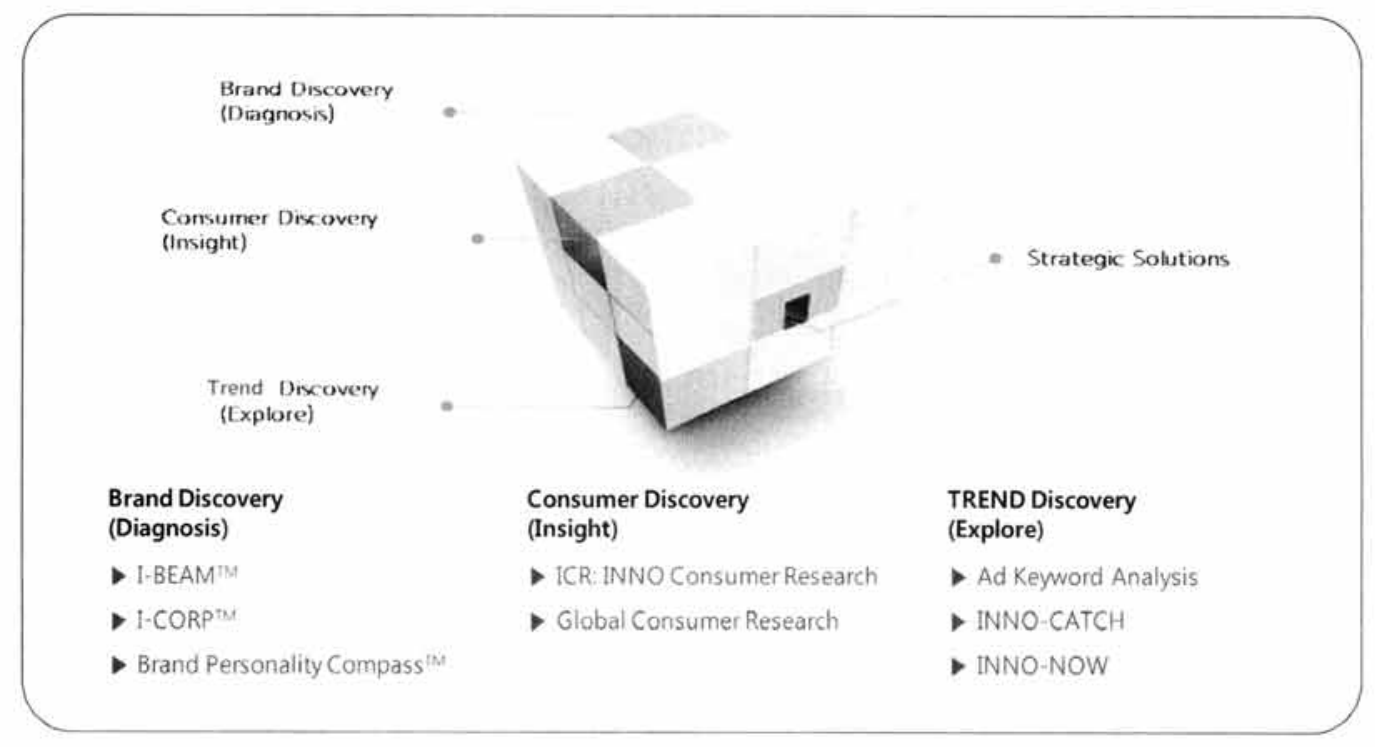


ments the Brand Personality Compass which measures a brand's personality adjectives and their complicated correlations based on psychology theories.

Based on these findings, the company publishes company magazines such as INNO-CATCH and INNO-NOW, making continuous efforts to understand present conditions and detect consumer trends and issues through organizing the keywords spanning from general society, new products, culture/consumer contents, and people.

\section{Global Business Performance}

INNOCEAN Worldwide has strived in various ways to succeed in the global environment with achieving global orientation as the company's management philosophy. The company has increased efficiency by handling media accounts of Hyundai Motors and Kia Motors together, and implemented differentiated media exposure approaches for each company's differentiation strategy. Built upon successful localization, the company is expanding its client base and offers various on-off line solutions (e.g.. Assurance + program, gas-lock program, transportation safety campaign in China, etc.).
Through such ongoing efforts, INNOCEAN Worldwide has been showing remarkable results, achieving an average growth rate of $63 \%$ for its billing in the last three years (the growth rate for Cheil Worldwide is 19\%), and a higher percentage of the billing comes from overseas relative to its competitors, with overseas billing taking up $74 \%$ of the whole in 2009, and $78 \%$ in 2011 (Cheil Worldwide: 59\% in 2009 and $66 \%$ in 2011). INNOCEAN Worldwide's remarkable headway in overseas billings since 2005 in Figure 7 shows that INNOCEAN Worldwide is successfully positioned as a global company.

Various awards that INNOCEAN Worldwide has won overseas also attest to the success of INNOCEAN Worldwide. In 2011, the company has won fifteen awards overseas, and also won four Bronze Lions in the Cannes Lions 2012. According to USA Today's '2012 Super Bowl Ad Meter', two Super Bowl ads produced and executed by IWA (INNOCEAN Worldwide Americas) ranked no. 7 (Cheetah: Hyundai Veloster Turbo Launch TV commercial) and no. 15 (Think Fast: Genesis Coupe R-spec TV commercial) among the Super Bowl ads. ${ }^{2)}$

In addition, INNOCEAN Worldwide has conducted the 2012 Australian Open sponsorship showing notable performance in sports marketing, and the company was also in charge of

2) INNOCEAN Worldwide was the first South Korean marketing and communications company to participate in the US Super Bowl advertisements, starting in 2010 (the ads were procuced by IWA: INNOCEAN Worldwide America). Super Bowl advertisements are famous for being an arena for major advertising and marketing companies worldwide to compete with their proudest campaigns. 
〈Figure 7〉 Overseas and Domestic billing by Year (years 2005 2011)

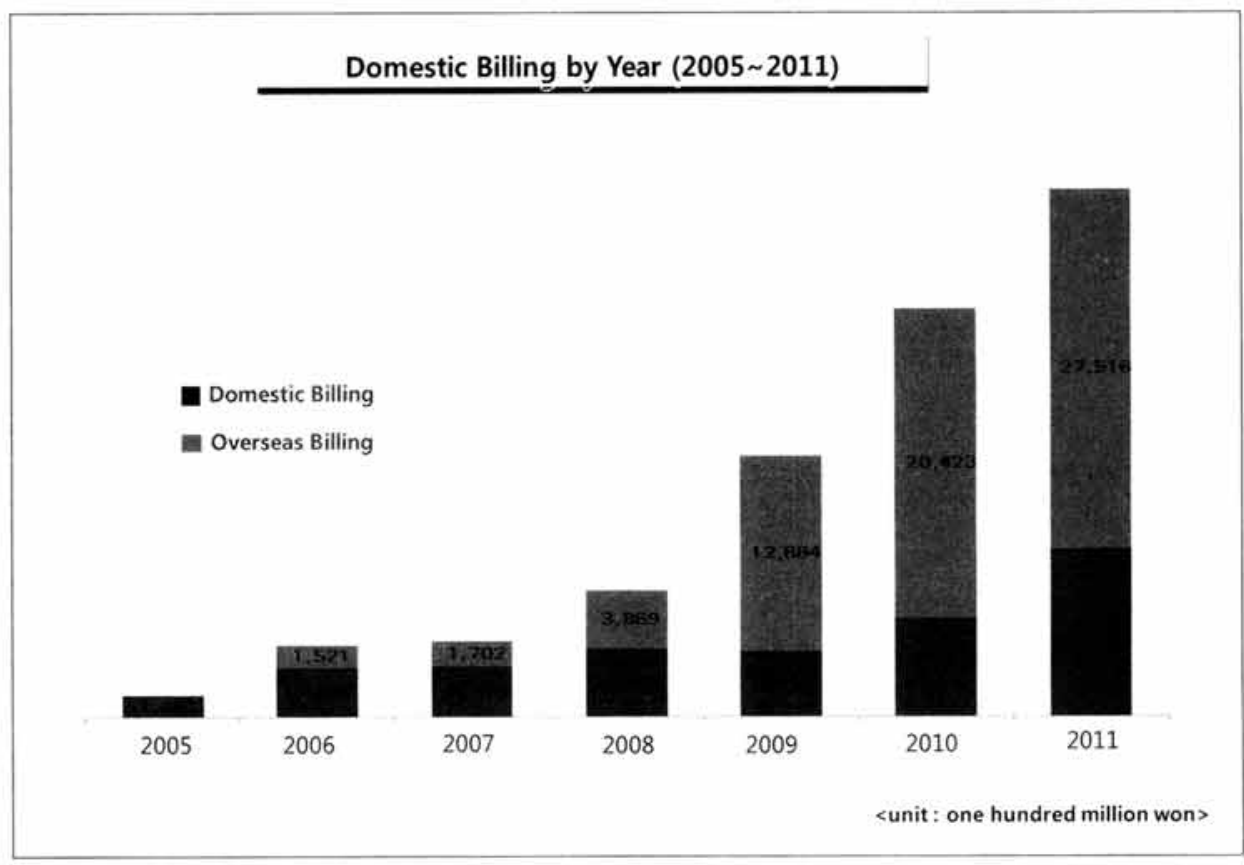

〈Figure 8〉 2012 United States Super Bowl Ad

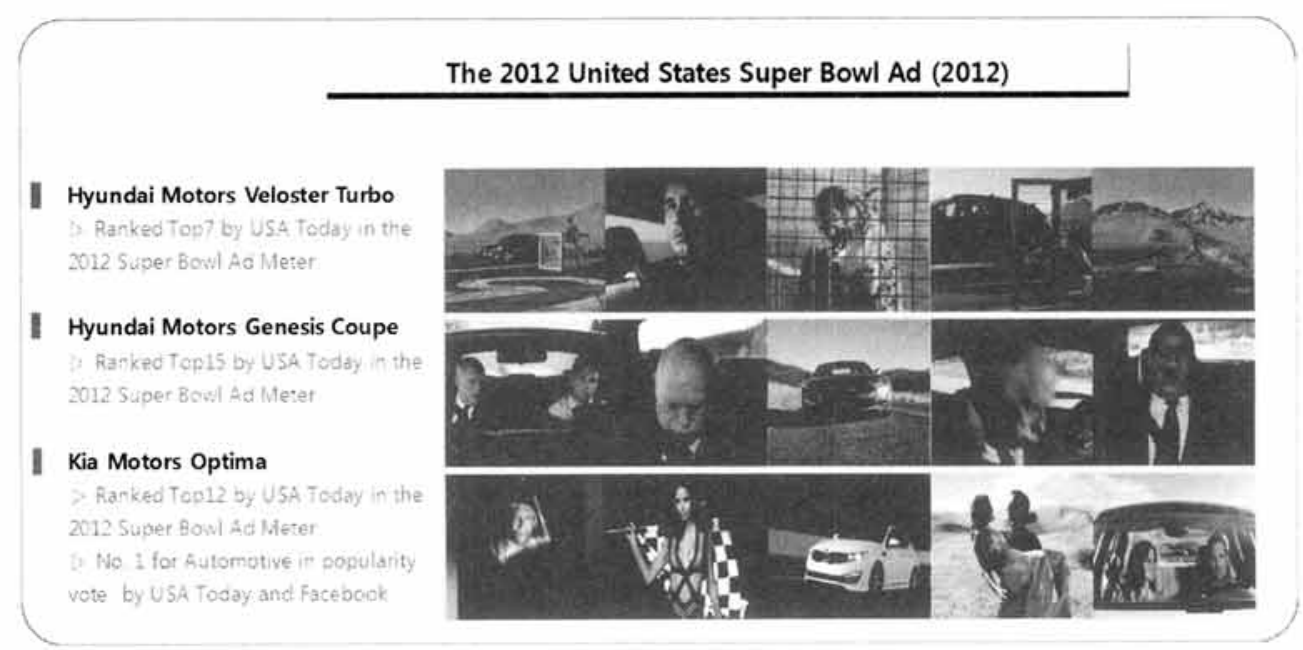

marketing the insignia of the Expo 2012 Yeosu Korea, making a solid foundation for the company's successful global business activities. 


\section{Concluding Remarks}

INNOCEAN Worldwide's rapid and successful global expansion was made possible owing to INNOCEAN Worldwide's confidence as a marketing and communications company to successfully fulfill its role in the global market. Through establishing overseas offices, INNOCEAN Worldwide was able to establish a premier global network in the industry and gained various operational experiences as well as various clients aside from Hyundai and KIA motors in several major regions, offering competitive marketing and communications services.

\subsection{Success Factors}

The success of INNOCEAN Worldwide can be summarized into five main factors.

First, INNOCEAN Worldwide held a strong passion as well as continuous commitment from the top management to enter the global market and establish a global network. Moreover, the company was able to provide a unique client service through propagating its resources accumulated from its global network.

Second, INNOCEAN Worldwide employed the talented local workforce and successfully achieved localization through overcoming language barriers, cultural differences, and the regional creative gaps.

Third is the company's clear orientation for a truly global company through effective implementation of the Global Resource Remix strategy, which incorporates the distinctive competencies of each overseas branch as a comprehensive company standard.

Fourth, the creation of the Discover System, a global knowledge management system, is considered as an important factor for the success of INNOCEAN Worldwide. Through this system, overseas branches are able to share each other's accumulated knowledge and experiences.

The fifth factor is the successful establishment of INNOCEAN Worldwide's unique Total Marketing Solution Service. Through this service. INNOCEAN Worldwide was able to offer integrated consulting services for strategic brand management and provide superior solutions.

\subsection{Challenges}

Although INNOCEAN Worldwide has made many achievements as a global marketing company within seven years of its establishment, there still is room for improvement in order to achieve continued growth.

First, the company needs to strengthen the global capability of the employees. As the business area of INNOCEAN Worldwide is expanding globally, all network employees need to enhance their ability to deal with global issues as such capability is a crucial and necessary asset for a global marketing and communications company. 
Second, the company needs to make effort to achieve true localization. There are $698 \mathrm{em}^{-}$ ployees total in the Overseas Business Group. consisting of 48 employees from the Seoul office, 36 expatriates, and 605 local employees in the overseas offices. Gradually, the company needs to reduce the sojourning employees from Korea and increase the proportion of outstanding local talents for a higher level of localization.

Third, the company needs to further enhance its Global Resource Remix operation strategy. Global Resource Remix strategy is a critical factor supporting INNOCEAN Worldwide's establishment as a successful global company. Therefore, INNOCEAN Worldwide has to support further improvement of this success factor. and make even more efforts to discover and share specialties by each sector.

Fourth, the company has to consider various strategies in entering the global market. Early stage of INNOCEAN Worldwide's global business was driven by the needs of Hyundai and KIA motors to designate a global network agency to help their global marketing and achieve successful entries in the overseas markets. Therefore, the initial entry to overseas markets was based on direct investments. This approach was inevitable as the automobile advertising industry required strict confidentiality protection. However, for INNOCEAN Worldwide to continue to grow in the global market, the company needs to be open to external resources. For example, INNOCEAN Worldwide may consider mergers and acquisitions (M\&A) in order to become a truly global company in the rapidly changing media environment. Through M\&A. INNOCEAN Worldwide should not seek mere growth in the scale of the company, but obtain the ability to respond quickly to the rapidly changing media environment. In addition, INNOCEAN Worldwide will need to extend opportunities to do business for diverse global brands through various global expansion strategies such as the establishment of INNOCEAN CBAC in China, which entered the market in the form of a Joint Venture (JV).

It will be interesting to watch INNOCEAN Worldwide will continue to grow as a company that is not merely a company with global operations but a truly global company, by developing the factors that have enabled its success and improving upon overcoming the challenges that the company is facing.

\section{References}

Chang, Sea Jin (2002), Global Management. Pakyoungsa.

Daniels, J.D. and L.H. Radebaugh (1989), "International entry-mode choice: A modified transaction-cost analysis approach," Journal of Marketing, vol.57. 19-38. 